\title{
Jerzy Rymarczyk
}

Uniwersytet Ekonomiczny we Wrocławiu

e-mail: jerzy.rymarczyk@ue.wroc.pl

ORCID: 0000-0002-8101-6375

\section{CŁA W WYMIANIE HANDLOWEJ MIEDZY UE I USA CUSTOMS DUTIES IN TRADE BETWEEN THE EU AND THE US}

DOI: $10.15611 / \mathrm{pn} .2019 .3 .07$

JEL Classification: F15, F36

Streszczenie: W artykule porównano taryfy celne stosowane w wymianie handlowej między UE i USA. Porównaniem objęto częstotliwość stosowania poszczególnych stawek celnych na importowane produkty, średnie stawki na szerokie kategorie towarów oraz produkty obciążone najwyższymi cłami u obu partnerów. Analiza wykazała, że poziom protekcjonizmu celnego UE jest istotnie wyższy w porównaniu z USA. Ze względu na większe rozmiary eksportu UE do USA opłaty celne importerów amerykańskich są jednak wyższe niż importerów unijnych. Również w imporcie do USA wiele grup towarowych i poszczególnych produktów jest obciążone wysokimi cłami. Wniosek końcowy wskazuje na konieczność powszechnej redukcji ceł na świecie w ramach WTO, gdyż ostatnia istotna redukcja odbyła się ćwierć wieku temu w wyniku negocjacji prowadzonych w trakcie Rundy Urugwajskiej GATT.

Słowa kluczowe: UE, USA, polityka handlowa, protekcjonizm, cło importowe, stawka celna.

Summary: The article compares customs tariffs used in trade between the EU and the USA. The comparison covered the frequency of applying individual customs tariffs on imported products, average rates for broad categories of goods and products loaded with the highest tariffs for both partners. The analysis showed that the level of EU customs protectionism is significantly higher than in the USA. However, due to the greater volume of EU exports to the USA, customs duties of American importers are higher than those of EU importers. Also in the import to the USA, many product groups and individual products are burdened with high tariffs. The final conclusion points to the necessity of universal reduction of customs duties in the world within the WTO, as the last significant reduction took place a quarter of a century ago as a result of negotiations conducted during the URANTA Round of GATT.

Keywords: EU, USA, trade policy, protectionism, import duty, customs duty. 


\section{Wstęp}

Jeszcze w trakcie kampanii wyborczej Donald Trump [Trump 2016] potępił nieuczciwy, z punktu widzenia USA, system handlu światowego. Już jako prezydent Trump w swoim memorandum [Trump 2018a] oskarżył kraje partnerskie o nieuczciwe praktyki handlowe, które doprowadziły do ogromnego deficytu handlowego USA (w 2017 r. - 811,2 mld USD). Wśród winowajców znalazła się m.in. Unia Europejska, w stosunku do której deficyt handlowy USA wyniósł w 2017 r. 153 mld USD. Unia spotkała się przede wszystkim z zarzutem stosowania ceł na towary importowane $\mathrm{z}$ USA znacznie wyższych niż te, które stosuje USA na produkty sprowadzane z UE.

Pierwszym istotnym posunięciem w ramach realizacji strategii handlowej Trumpa było nałożenie dodatkowych ceł na produkty ze stali i aluminium wobec wszystkich partnerów handlowych z wyjątkiem Kanady, Meksyku i Australii. Cła wprowadzone zostały w marcu 2018 r. - w wysokości $25 \%$ na import stali i 10\% na import aluminium [Felbermayr, Sandkamp 2018, s. 30]. Jako uzasadnienie wskazano nadwyżkę tych produktów na rynku światowym oraz względy bezpieczeństwa narodowego USA, któremu zagraża nadmierny import. Największa część importu objętego nowymi stawkami przypadła na UE. Stanowi ona ponad $1 / 4$ tego importu, a jego wartość wynosi 6,4 mld USD [Felbermayr, Sandkamp 2018, s. 33]. UE, tak jak i inne kraje, zapowiedziała wprowadzenie ceł odwetowych na różne towary importowane z USA i jednocześnie złożyła odwołanie w tej sprawie do WTO. Te działania wzmogły napięcie w stosunkach handlowych między stronami - pojawiła się groźba eskalacji protekcjonizmu i nowych wojen handlowych. Przedmiotem niniejszego opracowania nie jest jednak ocena polityki handlowej Trumpa i jej wpływu na sytuację $\mathrm{w}$ handlu międzynarodowym, lecz porównanie taryf celnych we wzajemnym handlu USA i UE, stosowanych w imporcie poszczególnych grup towarowych i wybranych produktów. Tym samym dokonana zostanie ocena, czy uzasadniony jest argument Trumpa o istotnie większej protekcji celnej UE w stosunku do USA.

\section{Cla w światowym systemie handlu}

Taryfy celne w handlu światowym, historycznie rzecz ujmując, są relatywnie bardzo niskie. Ale listy celne poszczególnych krajów wykazują zarówno znaczne asymetrie, jak i kominy celne. Ostatni raz cła w handlu między UE i USA były negocjowane i zostały uzgodnione w trakcie Rundy Urugwajskiej GATT (1986-1994). Obecnie obowiązujące stawki mają zatem prawie ćwierć wieku. Taryfy celne były wówczas efektem trudnego kompromisu między 124 członkami GATT, od tego czasu jednak warunki handlu światowego diametralnie się zmieniły. Liczba krajów członkowskich UE zwiększyła się z 12 do 28, do Światowej Organizacji Handlu dołączyło 40 nowych krajów, w tym Chiny, Wietnam i Rosja, ponadto znacznie wzrosła rola rynków wschodzących jako całości, a wśród nich zwłaszcza Chin. Oprócz tego, szybki postęp technologiczny doprowadził do znacznej obniżki kosztów w zakresie logistyki i komunikacji transgranicznej. To z kolei spowodowało rozszerzenie globalnych łańcuchów wartości dodanej, większe rozdrobnienie produkcji i znaczne 
zmniejszenie rodzimego udziału wartości dodanej w eksporcie brutto. Stąd wynikają nowe wyzwania dla światowej polityki handlowej [Aichele, Felbermayer, Heiland 2013, s. 17]. Pascal Lamy - były dyrektor Generalny Światowej Organizacji Handlu i unijny Komisarz ds. Handlu - ukuł termin „nowy świat handlu” [Lamy 2015]. Według niego „nowy świat” byłby tym, w którym przede wszystkim sprzedawane są półprodukty w ramach kompleksowych łańcuchów wartości, a najważniejszymi przeszkodami w handlu są bariery pozataryfowe. W przeciwieństwie do tego „stary świat" to ten, w którym produkty finalne jednego kraju sprzedawane są do innego kraju, a bariery handlowe występują przede wszystkim w formie ceł.

Reguły i zobowiązania celne WTO odzwierciedlają „stary świat”, dla „nowego świata" nie ma jeszcze odpowiednich międzynarodowych regulacji. Runda z Doha, która rozpoczęła się w 2001 r., z powodu nowych geostrategicznych realiów zakończyła się fiaskiem. Celem tej rundy negocjacyjnej, oprócz uzyskania dalszych preferencji dla krajów rozwijających się, miały być także kolejne obniżenie taryf celnych i ogólna modernizacja reguł WTO. Runda nie powiodła się, ponieważ niskie już cła w krajach rozwiniętych pozostawiają niewiele miejsca dla dalszych ustępstw na rzecz krajów rozwijających się. Z kolei kraje rozwijające się nie były skłonne obniżyć swoich relatywnie wysokich ceł przede wszystkim ze względu na silną konkurencję ze strony Chin.

Paradoksem „nowej” amerykańskiej polityki handlowej jest to, że za pomocą narzędzi właściwych dla „starego świata” chce działać w „nowym świecie”. Jeszcze w 2016 r. sytuacja była inna. Wówczas w ramach Transatlantyckiego Partnerstwa w dziedzinie Handlu i Inwestycji (Transatlantic Trade and Investment Partnership, TTIP) zamierzano nie tylko znieść w zasadzie wszystkie cła przywozowe, ale także zacieśnić współpracę w wielu kwestiach regulacyjnych, m.in. w zakresie ochrony inwestycji. Od momentu wyboru nowego prezydenta zaprzestano negocjacji traktatu. Jest interesujące, że to nie Donald Trump w spektakularnym geście przerwał negocjacje, ale wstrzymała je przede wszystkim strona europejska ze względu na zbliżające się wybory we Francji i w Niemczech. Jeśli wierzyć w oficjalne założenia polityki handlowej Trumpa, to właśnie dwustronne umowy, jak w m.in. TTIP, stanowią istotny cel jego aktywności [USTR 2017]. Donald Trump zarówno w trakcie kampanii wyborczej, jak i po objęciu urzędu prezydenta wielokrotnie twierdził, że istniejący system celny jest niesprawiedliwy dla jego kraju. USA bowiem wwożą do kraju zagraniczne towary niemal bezcłowo, podczas gdy inne kraje, takie jak UE, chronią swoje rynki za pomocą wysokich ceł [Trump 2018b]. W związku z tym zażądał dodatkowych obostrzeń celnych dla przywrócenia sprawiedliwości.

Czy Trump ma rację? Jak wysokie faktycznie są cła UE i jakich produktów dotyczą? Jak wygląda sytuacja europejskich eksporterów na rynku USA? Jakie wysokie są kwoty opłat celnych? Odpowiedzi na te pytania udzielono w dalszej części tekstu.

\section{Częstotliwość stosowania cel importowych w UE i USA}

Odpowiedź na pytanie, jakie są stawki celne UE i USA, wydaje się łatwa. Problem polega jednak na tym, że te dwie gospodarki różnie definiują taryfy celne w odniesieniu do kilku tysięcy produktów. Ponadto niektóre cła nie są ustalane jako odsetek wartości 
importowej, ale jako stały podatek na jednostkę towaru (za sztukę lub tonę). Są też kolejne komplikacje, zwłaszcza w sektorze rolnym, w którym istnieją w dalszym ciągu ograniczenia ilościowe (kwoty) i tak zwane stawki kwotowe. Co więcej, klasyfikacje produktów w obu krajach nie są w pełni porównywalne. Niemiecki Ifo Instytut stworzył kompleksową bazę ceł, która pokazuje preferencyjne lub oparte na KNU procentowe stawki celne w handlu wzajemnym prawie wszystkich krajów dla 5018 produktów (należących do 6-cyfrowego systemu produktów). Spośród tej ogólnej liczby $90 \%$ produktów jest faktycznie przedmiotem handlu między UE i USA, a 88\% wszystkich towarów jest jednocześnie wzajemnie eksportowane i importowane przez oba kraje. Są one zatem przedmiotem handlu wewnątrzgałęziowego [Felbermayr 2018].

Agregacja stawek celnych odnoszących się do poszczególnych produktów w jedną miarę, która pozwoliłaby na sumaryczny opis polityki celnej danego kraju, jest jednak problematyczna. Trudność polega na tym, że wysokość poszczególnych stawek celnych zawsze wpływa na popyt na importowane towary. Jeśli więc poszczególne stawki ważyć wartością importu, to otrzyma się przeciętną, która może znacznie zaniżać faktyczne zakłócenie handlu. Wtedy bowiem najwyższe cła są przeliczane przez najniższą wartość, a najniższe przez najwyższą wartość. Dlatego często stosuje się średnią nieważoną, co jednak nie pozwala ustalić, w jakiej ilości są nabywane bądź oferowane oclone produkty.

W tabeli 1 ukazano liczbę produktów obciążonych zróżnicowanymi stawkami cła, które UE stosuje w imporcie z USA oraz USA w imporcie z UE. Na 1328 produktów, co stanowi $26 \%$ wszystkich produktów, UE nakłada cło w wysokości od 0 do $1 \%$, a spośród nich 1246 produktów obłożonych jest stawką zerową. W USA 1993 produkty mają stawkę cła zawartą między 0 i 1\%, a 1802 produkty stawkę zerową. W UE cła wynoszące co najmniej 5\% pobierane są w imporcie 1926 produktów, a w USA dotyczy to 1307 produktów. W przypadku 660 produktów taryfy

Tabela 1. Liczba produktów objętych różnymi stawkami ceł we wzajemnym imporcie UE i USA w $2016 \mathrm{r}$.

\begin{tabular}{|l|c|c|}
\hline \multicolumn{1}{|c|}{ Stawki cła (w \%) } & $\begin{array}{c}\text { Liczba produktów } \\
\text { w imporcie UE }\end{array}$ & $\begin{array}{c}\text { Liczba produktów } \\
\text { w imporcie USA }\end{array}$ \\
\hline 0 do 1 & 1328 & 1993 \\
W tym 0 & 1246 & 1802 \\
\hline Powyżej 1 do 5 & 1773 & 1689 \\
\hline Powyżej 5 do 10 & 1265 & 852 \\
\hline Powyżej 10 do 15 & 412 & 266 \\
\hline Powyżej 15 do 20 & 83 & 143 \\
\hline Powyżej 20 do 25 & 45 & 27 \\
\hline Powyżej 25 do 30 & 25 & 24 \\
\hline
\end{tabular}

Źródło: Ifo Zolldatenbank; Darstellung des Ifo Instituts [Felbermayer 2018]. 
europejskie wynoszą co najmniej $10 \%$, a w 96 przypadkach co najmniej $30 \%$. W USA dotyczy to odpowiednio 472 i 24 produktów.

Wynika z tego, że pod względem wysokości stosowanych stawek celnych UE jest bardziej protekcjonistyczna niż USA, o czym przekonuje jeszcze inne porównanie. Mianowicie w przypadku 2391 produktów (48\% wszystkich produktów w imporcie UE) stawki UE są wyższe niż w USA, natomiast odwrotnie jest w przypadku 1483 produktów $(30 \%)$. W przypadku 1144 produktów stawki są identyczne u obu importerów, z czego w 1005 przypadkach (22\% wszystkich produktów) stawki w obu krajach wynoszą dokładnie zero.

\section{Przeciętne cła UE i USA według kategorii towarów}

Tabela 2 zawiera przeciętne stawki celne UE i USA na szerokie kategorie towarów. Z tabeli wynika, że w wielu grupach produktów UE stosuje przeciętnie wyższe cła niż USA. W odniesieniu na przykład do środków transportu średnia stawka cła w UE wynosi 4\%, a w USA 3\%. Chociaż różnica jest niewielka, to trzeba jednak wziąć pod

Tabela 2. Przeciętne stawki celne UE i USA na szerokie kategorie towarów

\begin{tabular}{|l|c|c|c|}
\hline \multicolumn{1}{|c|}{ Kategorie towarów } & Liczba produktów & $\begin{array}{c}\text { Stawka cła } \\
\text { UE }\end{array}$ & $\begin{array}{c}\text { Stawka cła } \\
\text { USA }\end{array}$ \\
\hline Środki transportu & 132 & 4,0 & 3,0 \\
Produkty chemiczne & 759 & 4,7 & 2,9 \\
Tłuszcze i oleje & 52 & 9,5 & 3,4 \\
Wyroby z drewna & 79 & 2,4 & 1,5 \\
Dzieła sztuki i antyki & 7 & 0,0 & 0,0 \\
Tworzywa sztuczne & 189 & 4,7 & 3,6 \\
Żywe zwierzęta & 194 & 19,8 & 3,1 \\
Artykuły spożywcze, napoje, tytoń & 181 & 18,3 & 8,3 \\
Wyroby ze skóry & 74 & 2,2 & 3,4 \\
Urządzenia mechaniczne i elektrotechniczne & 762 & 1,9 & 1,5 \\
Surowce mineralne & 151 & 0,3 & 0,3 \\
Instrumenty optyczne & 230 & 2,3 & 4,6 \\
Papier i tektura & 149 & 0,2 & 0,1 \\
Biżuteria & 52 & 0,6 & 2,2 \\
Obuwie & 55 & 7,3 & 8,0 \\
Tekstylia i odzież & 89 & 7,9 & 9,0 \\
Kamienie i szkło & 138 & 3,4 & 3,5 \\
Metale nieszlachetne & 587 & 2,1 & 2,0 \\
Różne towary & 131 & 2,5 & 2,8 \\
Broń i amunicja & 17 & 2,5 & 1,3 \\
Produkty pochodzenia roślinnego & 270 & 11,5 & 2,7 \\
\hline Wszystkie produkty 6-cyfrowej klasyfikacji & 5018 & 5,2 & 3,5 \\
\hline
\end{tabular}

Źródło: jak w tab. 1. 
uwagę, że za średnimi kryje się duże zróżnicowanie. Wszak w grupie tej znajdują się 132 produkty obciążone różnymi stawkami. W przypadku produktów pochodzenia rolniczego lub z branży spożywczej (poz. 3, 7, 8 i 21) cła UE są istotnie wyższe niż w USA. Natomiast przeciwnie jest w branży skórzanej, tekstylnej, obuwniczej i instrumentów optycznych (poz. 9,16,15 i 12) - cła USA są wyższe niż w UE.

W porównaniach tych należy również wziąć pod uwagę to, że obaj partnerzy często nakładają cła na towary, których już nie produkują lub jeszcze je produkują, ale w niewielkich ilościach; dotyczy to np. odzieży.

\section{Najwyższe cła we wzajemnej wymianie handlowej}

Interesujące jest pytanie, w odniesieniu do jakich produktów USA lub UE mają przewagę konkurencyjną, lecz z powodu wysokich ceł nie mogą ich eksportować. Aby na nie odpowiedzieć, wybrano produkty, na które cło importowe UE (USA) wynosi co najmniej 5\%, a całkowity eksport ponad pół miliona dolarów. Kryterium to w UE spełnia 87 dóbr. Na te dobra USA nakłada cła w wysokości co najmniej 5\%, a ich eksport z UE do krajów trzecich przekracza wartość $0,5 \mathrm{mln}$ USD. Średnia nieważona stawka cła importowego USA na nie wynosi $12,2 \%$, a średnia ważona stawka 8,5\% (zob. tab. 3). Oznacza to, że kilka bardzo wysokich stawek celnych hamuje eksport tych towarów i średnia stawka ważona wielkością importu jest znacznie zaniżona. Udział tych produktów w łącznym eksporcie UE do USA wynosi $13 \%$. Oczywiste jest, że wysokie cła hamują eksport UE. Konsumenci w USA w sumie za te 87 importowanych z UE towarów płacą cło w wysokości 2,04 mld USD. Całkowita kwota opłat celnych USA za 5018 produktów importowanych wynosi 7,1 mld USD.

Szczególnie mocno obciążone cłami amerykańskimi są produkty mleczne przeciętna stawka cła dla sześciu rodzajów tych produktów wynosi 20,3\%. Wartość importu tych towarów do USA z UE wynosi 1049 mln USD, a opłaty celne za nie 192 mln USD. W przypadku półciężarówek cło importowe USA wynosi przeciętnie $22 \%$; handel nimi jest obciążony cłem w kwocie 159 mln USD. Wysokie opłaty celne w wysokości ok. 100 mln USD wynikają również z eksportu z UE do USA torebek damskich, biżuterii i obuwia. Ponadprzeciętne stawki celne USA stosują również na produkty tytoniowe $(48,7 \%)$, żywność dla niemowląt $(22,9 \%)$ i czekoladę ( $9 \%)$. Z drugiej strony firmy europejskie osiągają w sprzedaży tych produktów stosunkowo wysokie przychody (ponad 0,5 mld USD w przypadku każdego z tych towarów), są więc najwyraźniej konkurencyjne.

Tabela 4 pokazuje sytuację amerykańskich eksporterów do UE. Wymienić należy przede wszystkim eksport z USA samochodów - o wartości 9,2 mld USD, obciążonych 10-procentową stawką celną. Kwota opłat celnych wyniosła w tym przypadku $920 \mathrm{mln}$ USD. Silnie obciążone są także różne produkty spożywcze. Za ich import do UE w wysokości 1,6 mld USD zapłacono cło w kwocie ponad 300 mln USD. Ekstremalnie wysokie są zwłaszcza cła w imporcie wołowiny; stawka na ten towar 
Tabela 3. Produkty obciążone wysokimi cłami w imporcie do USA

\begin{tabular}{|c|c|c|c|c|}
\hline Wyszczególnienie & $\begin{array}{l}\text { Liczba } \\
\text { pozycji }\end{array}$ & $\begin{array}{l}\text { Cła KNU } \\
(\mathrm{w} \%)\end{array}$ & $\begin{array}{c}\text { Import do USA } \\
\text { z UE (mld USD) }\end{array}$ & $\begin{array}{l}\text { Opłaty celne } \\
\text { (mld USD) }\end{array}$ \\
\hline Produkty ropopochodne & 1 & 7,2 & 9700 & 703 \\
\hline Produkty mleczne & 6 & 20,3 & 1049 & 192 \\
\hline Półciężarówki & 4 & 22,4 & 683 & 159 \\
\hline Tworzywa sztuczne & 19 & 6,1 & 2120 & 127 \\
\hline Torebki & 4 & 8,3 & 1277 & 105 \\
\hline Biżuteria z metali szlachetnych & 2 & 7,0 & 1719 & 105 \\
\hline Obuwie & 4 & 9,2 & 1533 & 99 \\
\hline Wyroby ceramiczne & 2 & 9,3 & 899 & 79 \\
\hline Odzież & 7 & 12,6 & 551 & 71 \\
\hline Pozostałe produkty spożywcze & 1 & 10,7 & 562 & 60 \\
\hline Czekolada & 4 & 9,0 & 529 & 49 \\
\hline Chemikalia organiczne & 3 & 5,4 & 777 & 41 \\
\hline Karma dla zwierząt & 1 & 24,7 & 152 & 38 \\
\hline Łożyska kulkowe & 4 & 5,8 & 610 & 35 \\
\hline Cukier & 2 & 35,7 & 255 & 33 \\
\hline Tytoń, wyroby tytoniowe & 4 & 48,7 & 74 & 31 \\
\hline Artykuły z tytanu & 1 & 8,1 & 267 & 23 \\
\hline Smary & 3 & 6,5 & 268 & 17 \\
\hline Sosy i koncentraty & 2 & 6,4 & 198 & 14 \\
\hline Pozostałe produkty zbożowe & 1 & 17,8 & 63 & 11 \\
\hline Oprawy oświetleniowe & 1 & 5,1 & 189 & 10 \\
\hline Napoje bezalkoholowe & 1 & 13,7 & 68 & 9 \\
\hline Wiertła & 1 & 5,4 & 173 & 9 \\
\hline Elementy aluminiowe & 1 & 5,7 & 116 & 7 \\
\hline Kwiaty cięte & 1 & 6,2 & 92 & 6 \\
\hline Papierowe artykuły sanitarne & 1 & 7,6 & 52 & 4 \\
\hline Kosmetyki & 1 & 5,4 & 59 & 3 \\
\hline Żywność dla niemowląt & 1 & 20,9 & 12 & 3 \\
\hline Mrożone produkty ziemniaczane & 1 & 7,2 & 19 & 1 \\
\hline Płatki śniadaniowe & 1 & 5,7 & 22 & 1 \\
\hline Mrożone części kurczaka & 1 & 7,5 & 0 & 0 \\
\hline Olej sojowy & 1 & 19,1 & 0 & 0 \\
\hline Łącznie 87 produktów wrażliwych & 87 & & 24078 & 2044 \\
\hline Udział procentowy (5018 produktów) & 1,7 & & 6,0 & 28,8 \\
\hline Średnia ważona & & 8,5 & & \\
\hline Średnia nieważona & & 12,2 & & \\
\hline
\end{tabular}

Źródło: jak w tab. 1.

wynosi $70 \%$. Cło na wieprzowinę wynosi $26,4 \%$, na jabłka $17,3 \%$, a na winogrona $20,2 \%$. USA maja przewagę konkurencyjną na rynkach wszystkich wymienionych tu produktów, ale z powodu wysokich ceł faktyczna ich sprzedaż jest niewielka. 
Tabela 4. Produkty obciążone wysokimi cłami w imporcie do UE

\begin{tabular}{|c|c|c|c|c|}
\hline Wyszczególnienie & $\begin{array}{l}\text { Liczba } \\
\text { pozycji }\end{array}$ & $\begin{array}{c}\text { Cła KNU } \\
(\mathrm{w} \%)\end{array}$ & $\begin{array}{c}\text { Import do UE } \\
\text { z USA }\end{array}$ & $\begin{array}{l}\text { Opłaty celne } \\
\text { (mld USD) }\end{array}$ \\
\hline Samochody osobowe & 7 & 10,0 & 900 & 921 \\
\hline Różne artykuły spożywcze & 18 & 25,8 & 1600 & 319 \\
\hline Tworzywa sztuczne & 28 & 6,3 & 4800 & 299 \\
\hline Mięso wołowe, świeże i mrożone & 3 & 67,9 & 214 & 133 \\
\hline Chemikalia organiczne & 6 & 6,0 & 2000 & 128 \\
\hline Pozostałe chemikalia & 6 & 6,0 & 1900 & 112 \\
\hline Metale nieszlachetne & 6 & 6,9 & 1500 & 100 \\
\hline Filety rybne & 2 & 9,7 & 578 & 58 \\
\hline Odbiorniki telewizyjne & 1 & 8,8 & 488 & 43 \\
\hline Motorowery & 1 & 6,0 & 668 & 40 \\
\hline Tytoń surowy & 1 & 7,2 & 283 & 20 \\
\hline Chemia rolnicza & 3 & 6,0 & 312 & 19 \\
\hline Orzechy włoskie & 1 & 5,1 & 319 & 16 \\
\hline Farby & 3 & 6,2 & 226 & 14 \\
\hline Łożyska kulkowe & 1 & 8,0 & 170 & 14 \\
\hline Smary i kleje & 2 & 5,7 & 179 & 11 \\
\hline Półciężarówki & 4 & 15,1 & 77 & 11 \\
\hline Kosmetyki & 1 & 6,5 & 116 & 8 \\
\hline Chemikalia nieorganiczne & 2 & 5,5 & 133 & 7 \\
\hline Mięso wieprzowe & 3 & 26,4 & 11 & 3 \\
\hline Winogrona & 1 & 20,2 & 14 & 3 \\
\hline Palone ziarna kawy & 1 & 7,5 & 35 & 3 \\
\hline Tkaniny i odzież & 2 & 6,7 & 35 & 2 \\
\hline Jabłka & 1 & 17,3 & 7 & 1 \\
\hline Kurczaki, świeże i mrożone & 2 & 20,6 & 2 & 1 \\
\hline Ciągniki & 1 & 16,0 & 2 & 0 \\
\hline Nawozy sztuczne & 1 & 6,5 & 4 & 0 \\
\hline Autobusy & 3 & 13,0 & 1 & 0 \\
\hline Pomarańcze & 1 & 5,4 & 0 & 0 \\
\hline Łącznie 112 produktów wrażliwych & 112 & & 24873 & 2285 \\
\hline Udział procentowy w 5018 produktów & 2,2 & & 8,9 & 40,1 \\
\hline Średnia ważona & & 9,2 & & \\
\hline Średnia nieważona & & 12,3 & & \\
\hline
\end{tabular}

Źródło: jak w tab. 1.

Stosunkowo wysokie stawki cła obowiązują w UE również na półciężarówki, (15\%), motocykle (6\%), autobusy (13\%) i winogrona (20,2\%). Import tych towarów do UE jest de facto zerowy, choć do innych krajów, które mają niższe bariery celne, dostawy USA są znaczne. 
Ogólnie eksport z USA do UE produktów wyszczególnionych w tab. 4 jest obciążony cłami w wysokości 2,3 mld USD (stan w 2015 r.). Na wszystkie 5018 produktów opłaty celne wyniosły 5,7 mld USD.

\section{Zakończenie}

Przeprowadzona analiza potwierdza opinię Donalda Trumpa o wyższym protekcjonizmie celnym UE w porównaniu z USA we wzajemnym handlu. Średnia nieważona stawka celna UE w imporcie UE wynosi $5,2 \%$ podczas gdy w USA 3,5\%. W przypadku $48 \%$ wszystkich produktów (z 5018 poddanych obserwacji) stawki cła UE są wyższe niż w USA, natomiast odwrotnie jest w przypadku w 30\%. W wielu grupach produktów UE stosuje przeciętnie wyższe cła niż USA. Wymienić należy przede wszystkim import z USA samochodów o wartości 9,2 mld USD, obciążonych 10-procentową stawką celną. Silnie obciążone są także różne produkty spożywcze. Ekstremalnie wysokie są zwłaszcza cła w imporcie wołowiny - stawka na ten towar wynosi $70 \%$. Cło na wieprzowinę wynosi $26,4 \%$, na jabłka $17,3 \%$, a na winogrona $20,2 \%$. USA mają przewagę konkurencyjną na rynkach wszystkich wymienionych tu produktów, ale z powodu wysokich ceł faktyczna ich sprzedaż jest niewielka.

Z kolei w imporcie z UE do USA szczególnie mocno obciążone cłami są produkty mleczne - przeciętna stawka cła dla sześciu rodzajów tych produktów wynosi $20,3 \%$. W przypadku półciężarówek cło importowe wynosi przeciętnie $22 \%$. Ponadprzeciętne stawki celne stosują USA również na produkty tytoniowe (48,7\%), żywność dla niemowląt $(22,9 \%)$ i czekoladę ( $9 \%)$.

Można zatem ocenić, że UE w żadnym razie nie jest wzorem dla zwolenników wolnego handlu, za którym chętnie się opowiada. Jeśli więc prezydent Trump narzeka na „ogromne cła” na towary eksportowane do Unii, to w pewnym stopniu ma rację. To samo jednak dotyczy, choć na mniejszą skalę, barier celnych USA stosowanych na wiele importowanych produktów. Najwyższy zatem czas, aby doprowadzić w ramach WTO do powszechnej redukcji pozostałych taryf celnych. Wymagają tego zmiany w gospodarce światowej i w handlu międzynarodowym, które zaszły od zakończonej ćwierć wieku temu Rundy Urugwajskiej GATT.

\section{Literatura}

Aichele R., Felbermayr G., Heiland I., 2013, Neues aus der Basarökonomie, Ifo Schnelldienst nr 6. Felbermayar G., 2018, Zölle im transatlantischen Handel: Worauf, wie viel und wie gerecht?, Ifo Schnelldienst, $\mathrm{nr} 6$.

Felbermayr G., Sandkamp A.,2018, Trumps Importzölle auf Stahl und Aluminium, Ifo Schnelldienst, nr 6. 
Lamy P., 2015, Looking Ahead: The New World of Trade, Jan Tumlir Lecture, ECIPE, Brüssel, http:// www.globalpolicyjournal. com/blog/28/05/2015/looking-ahead-new-world-trade (dostęp 05.03.2019).

Trump D., 2016, Declaring American Economic Independence, Alumisource Factory, Monessen, Pennsylvania; 28 Juni.

Trump D., 2018a, Remarks by President Trump at Signing of a Presidential Memorandum Targeting China's Economic Aggression, The White House, 22. March.

Trump D., 2018b, Tweet z 3 marca, https://twitter.com/realDonaldTrump/status/969994273121820672 (dostęp 05.03.2019).

USTR, 2017, 2017 Trade Policy Agenda and 2016 Annual Report of the President of the United States on the Trade Agreements Program, Office of the United States Trade Representative, https://ustr.gov/ sites/ default/files/files/reports/2017/AnnualReport/AnnualReport2017.pdf. (dostęp 05.03.2019). 